\title{
THE EFFECT OF WORK LIFE QUALITY ON EMOTIONAL EXHAUSTION AND JOB EMBEDDEDNESS: THE ROLE OF PERFECTIONISM
}

\author{
DOI: 10.17261/Pressacademia.2018.852 \\ PAP- V.7-2018(5)-p.31-38
}

Pelin Kanten ${ }^{1}$, Selahattin Kanten ${ }^{2}$, Aylin Ozer ${ }^{3}$, Fatma Bulbul ${ }^{4}$

${ }^{1}$ Canakkale Onsekiz Mart University, Faculty of Political Science, Canakkale, Turkey. pelinkanten@comu.edu.tr, ORCID: 0000-0002-6487-0203

${ }^{2}$ Canakkale Onsekiz Mart University, Faculty of Biga Applied Science, Canakkale, Turkey. skanten@comu.edu.tr, ORCID: 0000-0001-7414-8495

${ }^{3}$ Canakkale Onsekiz Mart University, Faculty of Political Science, Canakkale, Turkey. aylinnozerr@outlook.com, ORCID: 0000-0001-7710-990X

${ }^{4}$ Canakkale Onsekiz Mart University, Faculty of Political Science, Canakkale, Turkey. fatmabulbul0@gmail.com, ORCID: 0000-0001-9394-506X

To cite this document

Kanten, P., Kanten, S., Ozer, A., Bulbul, F. (2018). The effect of work life quality on emotional exhaustion and job embeddedness: the role of perfectionism. PressAcademia Procedia (PAP), V.7, p.31-38.

Permemant link to this document: http://doi.org/10.17261/Pressacademia.2018.852

Copyright: Published by PressAcademia and limited licenced re-use rights only.

\section{ABSTRACT}

Purpose- This study aims to investigate the effect of work life quality on emotional exhaustion and job embeddedness levels of employees and the mediating role of perfectionism. Within the literature, studies suggest that some of the organizational factors lead to both positive and negative outcomes. Therefore, emotional exhaustion, job embeddedness and perfectionism are considered as significant consequences of work life quality in scope of the study.

Methodology- For the purpose of the research, the data which were collected from 190 employees in banking industry by the survey method were analyzed by using hierarchical regression analysis.

Findings- The results of study revealed that while quality of work life has positive and significant effect on job embeddedness levels of employees also it has a negative and significant effect on emotional exhaustion.

Conclusion- However, when perfectionism has a positive and significant effect on employees' job embeddedness levels, it has also a negative effect on emotional exhaustion levels of employees. In addition, perfectionism has partially mediating role in the relationship between quality of work life and job embeddedness. Moreover, perfectionism has partially mediating role in the relationship between quality of work life and emotional exhaustion.

Keywords: Quality of work life, job embeddedness, emotional exhaustion, perfectionism.

JEL Codes: M10, M20, M54

\section{INTRODUCTION}

As a result of the globalization, competitiveness and technological improvements a crucial dynamism has been emerged in working area which have also changed employees outlook of what a good organization is (Ajala, 2013: 46). Due to the working life becomes more complex and ambiguous, organizations need to provide positive working conditions in order to attract and retain qualified employees (Lai et al., 2012: 437). In other words, because of the human resources are considered as crucial and strategic resources of business world, it is seen success of organizations based on effective and efficient utilization of their human resources. In order to utilization of human resources most efficiently there is an increasing need for more broad recognition of favorable procedures, practices and structures (Parvar, et al., 2013: 135). Therefore, it can be expressed that for achieving objectives, implementing organizational vision and mission and also getting benefit from human resources, organization have to maintain and operate positive conditions which are characterized under the title of quality of work life (Ganguly, 2010: 209). Quality of work life refers to a philosophy, a set of precepts which keep employees are the most important resources in the organization as they are responsible and competent to make precious contribution. Quality of work life includes working conditions such as health and safety issues, monetary and nonmonetary benefits, relationships between employees and development opportunities and management styles through which provides employees to be treated in respect and dignity (Tabassum et al., 2011: 17). In other words, quality of work life provides employees to maintain cooperative and good working relationships and facilitates them to exhibit more positive organizational attitudes and behaviors (Kashani, 2012: 9526). Previous literature, it is seen researches suggested that quality of work life bring out some consequences for individuals and organizations such as job satisfaction, career satisfaction, career achievement, organizational commitment, turnover intention, burnout, job performance, organizational 
effectiveness and job embeddedness (Kanten, 2014: 254). It is emphasized that quality of work life provides positive outputs both employees and organizations rather than negative consequences such as sabotage, turnover intention, absenteeism, emotional exhaustion and etc (Nair, 2013: 34). Accordingly, it is possible to express that due to the work life quality's importance on employees' attitudes and behaviors, its consequences should be explored. In this context, this study aims to examine some of the positive and negative outcomes of work life quality in the banking industry. From the scope of the positive outcomes, job embeddedness and perfectionism were evaluated. On the other hand, in consideration of negative consequences, emotional exhaustion was examined. However, there is no research in the existing literature yet examining the relationships among quality of work life, job embeddedness, emotional exhaustion and perfectionism together. Consequently, this study aims to investigate some individual and organizational consequences of quality of work life, so it attempts to add contribution to the literature.

\section{THEORETICAL FRAMEWORK AND HYPOTHESES DEVELOPMENT}

Quality of work life (QWL) generally has been conceptualized such as quality of work, employment quality and humane working life or decent work. It is suggested that QWL as a multi-dimensional construct and there is no universally accepted definition of this concept. Simply, quality of work life refers to the employees' perception, evaluation and satisfaction with their work and total working environment. In other words, QWL defined as "the quality of the relationship between employees and the total working environment which provides work-life balance, a sense of belonging to a working group, and a sense of being worthy and respectable" (Korunka et al., 2007: 290; Taher, 2013: 581). In literature, it is seen that quality of work life has been classified by the researchers based on the different views. One of the best-known classification is the Walton's (1974) categorization which includes eight dimensions such as adequate and fair compensation, safe and healthy work environment, growth and security, development of human capabilities, total life space, constitutionalism, social integration, social relevance (Parvar et al., 2013: 136-138; Tulasi and Vijayalakshmi: 2013: 9). In addition, quality of work life includes variety of processes, strategies, techniques and management styles which aims to enhance performance and satisfaction of employees and so it leads to raising of organizational effectiveness. However, maintaining quality of life has become crucial in order to facilitate exhibition of employees' positive attitudes and behaviors towards to their organizations and colleagues. In other words, while employees perceive working conditions transparent and fair and also believe that their expectations have full filled, they tend to show more positive attitudes and behaviors (Kanten, 2014: 252). Therefore, providing positive working conditions or quality of work life is regarded as an important component for organization as to the increasing performance, organizational commitment, organizational effectiveness and lowering absenteeism, turnover and exhaustion (Penny and Joanne, 2013: 348). Due to its vital role for both organizations and employees, it is seen researchers have focus on quality of work life antecedents, components and consequences. According to the previous literature, researchers suggested that quality of work life bring some positive and negative consequences for employees and organizations such as organizational commitment, productivity, organizational identification, job satisfaction, job performance, job embeddedness, work engagement, turnover intention, abseenteeism, burnout, stress and etc. (Gupta and Sharma, 2011: 80; Lai et al., 2012: 437). In this study, as a consequences of quality of work life; perfectionism, job embeddedness and emotional exhaustion have been examined from the employees' perspective.

Job embeddedness represents a large group of factors which effect an employee's decision to remain or leave the job (Dawley and Andrews, 2012: 478). It refers to the collection of forces that lead to keep employees in the job or organization. Job embeddedness includes individuals' links to the job and organization, perception of person-job fit and the sacrifice related with costs of leaving the organization both financial and social (Halbesleben and Wheeler, 2008: 243). Therefore, it is possible to express that job embeddedness is considered as a useful and positive state for organizations and individuals. Because employees who have high level of job embeddedness, they may perform their job better, not prone to absenteeism or turnover intention and tend to exhibit more positive attitudes (Kanten et al., 2015: 1360). Due to its importance, it is seen prior researches has drawn antecedents of job embeddedness, but in a limited availability. For example Giosan (2003) has revealed that demographic characteristics such as gender, number of children, age and other factors like personality traits and strength of attachment have a significant effect on job embeddedness levels of employees. However, Yao et al. (2004) emphasized that selection and socialization process, organizational justice, and job characteristics considered as a predictors of job embeddedness. Zhao et al. (2012) and Alqarni (2016) asserted that quality of work life has a positive and significant effect on job embeddedness. On the other hand, it is seen while Edais (2013) have underlined the individual determinants of the job embeddedness such as self-efficacy and polychronicity; Huysse-Gaytandjieva et al., (2016) asserted job embeddedness levels of employees were affected self-esteem, self-determination and self-compassion characteristics. Gong (2009) found that some of the dimensions of big five personality traits have a significant relationship with the job embeddedness levels of employees. In this context, it can be inferred that some personal and organizational factors needed to be evaluated as an antecedents of job embeddedness, so the following hypotheses are proposed:

$\mathrm{H}_{1}$ : Quality of work life influences employees' job embeddedness levels.

$\mathrm{H}_{2}$ : Perfectionism influences employees' job embeddedness levels.

Perfectionism refers one of the most important characteristics which reveals the main differences between human beings. It represents emotional trait and defined as putting high measures in performance criteria and evaluation process (Forghani et al., 2013: 52). In other words, perfectionism considered as a specific personality characteristics that involves high personal standards, excessive self-criticism or concerns about maintaining personal standards (Rice et al., 2014: 368). In literature, it is seen researchers suggested that perfectionism regarded as one of the significant predictors of the positive workplace attitudes such as workaholism, work engagement, work involvement, psychological well-being and job embeddedness. Besides, it has been asserted that perfectionism has also some negative consequences for individuals such as anxiety, depression, psychosomatic disorders, and chronic sense of failure, indecisiveness, procrastination, negative affect, burnout and exhaustion (Kanten and Yeşiltaş, 2015: 1368). Moreover, researchers have emphasized that there are some indicators of perfectionism like achievement motivation, achievement striving and culture (Özbilir et al., 2014: 256). For example Madjar et al. (2015) found that encouragement of collective work, autonomy, constructive feedback and supportive conditions 
lead individuals to have perfectionistic tendency. Thus, it is possible to express that positive, supportive and favorable working conditions may lead employees to have more perfectionist in their work and social life, so the following hypotheses are proposed:

$\mathrm{H}_{3}$ : Perfectionism influences employees' emotional exhaustion levels.

$\mathrm{H}_{4}$ : Quality of work life influences employees' perfectionism levels.

Emotional exhaustion is considered as the most important dimension of burnout which indicates individuals' stress levels representing a feeling of energy loss. It is characterized as the feelings of individuals such as emotionally overextended, extreme tiredness, depletion and a feeling of being drained to cope with the demands (Akpınar et al., 2013: 171). When these demands exceed what an individual is able to afford during their work and social life, emotional exhaustion may emerge. In other words, due to the individuals remain under the deep stressful conditions and huge demands, it is expected that emotional exhaustion triggered (Wu and Hu, 2009: 149). Accordingly, in literature it is seen researchers asserted that some various organizational and individual factors such as demographic variables, personality, social support, personality traits, perfectionism, and self-esteem may lead to increasing of emotional exhaustion (Kanten and Yeşiltaş, 2015: 1369). For example studies of Tuuli and Karisalmi (1999); Korunka et al. (2007); Marofi et al. (2016); Khoo and Tan (2017) asserted that quality of work life and working conditions are the significant predictors of burnout and emotional exhaustion. In addition, it is also supposed that perfectionism has a mediating effect between the relationship working conditions and individual attitudes. That is, when employees perceived their working conditions as a favorable and also have a tendency to perfectionism, it is expected that exhibit more positive attitudes and the following hypotheses are proposed:

$\mathrm{H}_{5}$ : Quality of work life influences employees' emotional exhaustion levels.

$\mathrm{H}_{6}$ : Perfectionism has a mediating role on the relationship between quality of work life and job embeddedness.

$\mathrm{H}_{7}$ : Perfectionism has a mediating role on the relationship between quality of work life and emotional exhaustion

\section{Figure 1: Research Model}

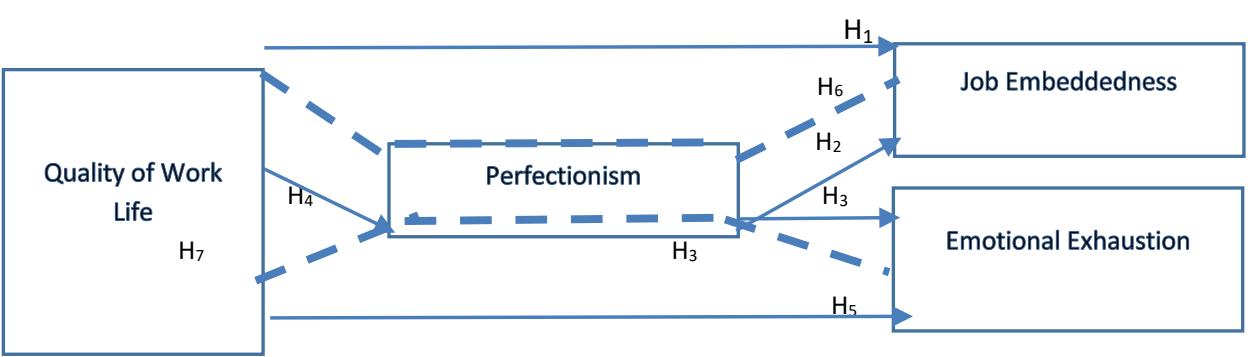

\section{RESEARCH METHODOLOGY}

\subsection{Sample and Procedures}

The present sample of the research was composed of six companies in the banking industry which are located in Çanakkale province. The participants consist of 190 employees who have been working in these companies determined by a convenient sampling method. From the 250 questionnaires that have been sent out, 210 have been returned, representing a response rate of $90 \%$. After the elimination of the cases that have incomplete data and outliers, 190 questionnaires (76\%) have been accepted as valid and included in the evaluations. However, questionnaire survey method is used for data collection in this study. The questionnaire form contains four different measures related to research variables.

\subsection{Measures}

The measures used in the questionnaire forms have been adapted from the previous studies in the literature. All measures have been adapted to Turkish by the lecturers and a pilot study has been conducted for the validity of these measures. Before the distribution of the survey to the actual sample, a pilot study was conducted in order to determine whether the questions would be understood properly and to check the reliability of the scales. As a result of the pilot study, some corrections were made in the questionnaire forms. A Likert-type metric, that is, expressions with five intervals has been used for answers to the statements of survey. Anchored such; "1- strongly disagree, 2- disagree, 3- agree or not agree, 4- agree, 5-strongly agree". Moreover, 6 demographic questions were included in the questionnaire form. Firstly, all scales were subjected to the exploratory factor analyses to check the dimensions, and then confirmatory factor analyses were applied to all scales.

- Quality of Work Life Scale: Employees' quality of work life perception was measured with 36 items from Timossi et al. (2008) study. Exploratory factor analyses using principle component analysis with varimax rotation was applied to the adapted scale to check the dimensions. As a result of the varimax rotation of the data related to the quality of work life scale variables, 17 items were removed from the analysis due to the factor loading under 0.50. Additionally, four factor solutions; (social integration \& use and development of human capacities \& total life space $\&$ adequate and fair compensation \& social relevance) were obtained in accordance with the theoretical structure. Some examples of the items asked to the employees are as follows: "I am satisfied with my salary in this organization"; "My work not to allow enough time for my private life"; "I am satisfied with the image of this organization". 
- Job Embeddedness Scale: Employees' job embeddedness levels were measured with 7 items from Crossley et al. (2007) study. Exploratory factor analyses using principle component analysis with varimax rotation was applied to the adapted scale to check the dimensions. As a result of the varimax rotation of the data related to the job embeddedness scale variables, 1 items were removed from the analysis due to the factor loading under 0.50. Additionally, one factor solution was obtained in accordance with the theoretical structure. Some examples of the items asked to the employees are as follows: "It would be easy for me to leave this organization"; "I feel attached to this organization".

- Emotional Exhaustion Scale: Employees' emotional exhaustion levels were measured with 8 items from Karatepe (2013) study. Exploratory factor analyses using principle component analysis with varimax rotation was applied to the adapted scale to check the dimensions. As a result of the exploratory factor analysis of the data related to the emotional exhaustion scale, one factor solution obtained in accordance with the theoretical structure. Some examples of the items are as follows: "I feel emotionally drained from my work"; "I feel used up at the end of the workday".

- Perfectionism Scale: Perfectionism levels were measured with 13 items short scale developed by Rice et al. (2014). As a result of the varimax rotation of the data related to the perfectionism scale variables, 2 items were removed from the analysis due to the factor loading under 0.50. Additionally, two factor solutions; (standards and discrepancy) were obtained in accordance with the theoretical structure. Example items include; "I set very high standards for myself"; "I am hardly ever satisfied with my performance".

Table 1: Summary Table of Exploratory Factor and Reliability Analyses

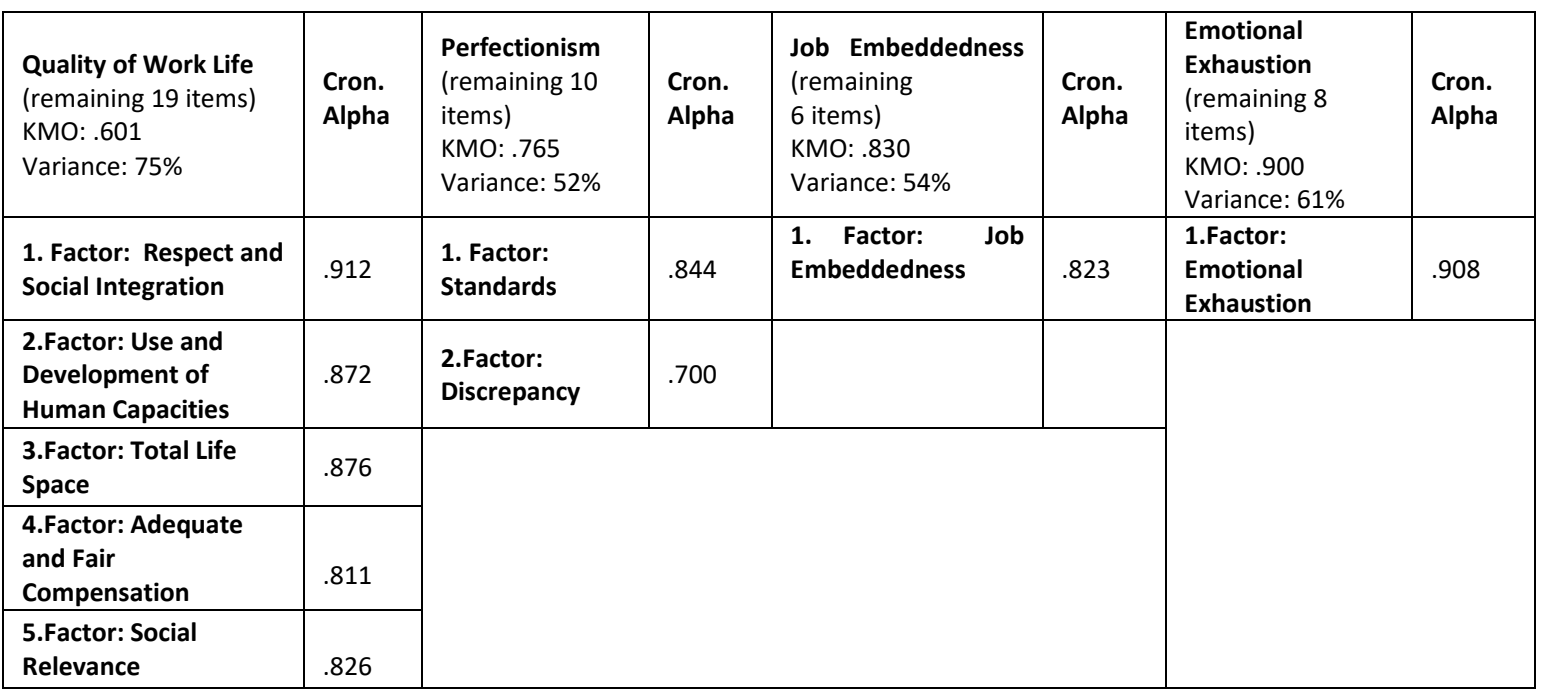

After the exploratory factor analyses, the confirmatory factor analysis has been conducted by Lisrel 8.8 for all scales. Goodness of fit indexes is presented in Table 1. It can be seen that all of the fit indexes fall within the acceptable ranges (Schermelleh-Engel et al., 2003: 52; Meydan and Şeşen, 2011: 35).

Table 2: Goodness of Fit Indexes of the Scales

\begin{tabular}{lcccccccccc}
\hline Variables & $\chi^{2}$ & df. & $\begin{array}{l}\chi^{2} / \text { df } \\
\leq \mathbf{5}\end{array}$ & $\begin{array}{l}\text { GFI } \\
\geq .85\end{array}$ & $\begin{array}{l}\text { AGFI } \\
\geq .80\end{array}$ & $\begin{array}{l}\text { CFI } \\
\geq .90\end{array}$ & $\begin{array}{l}\text { IFI } \\
\geq .90\end{array}$ & $\begin{array}{l}\text { NNFI } \\
\geq .90\end{array}$ & $\begin{array}{l}\text { RMSEA } \\
\leq \mathbf{0 . 0 8}\end{array}$ \\
\hline QWL & 253.76 & 139 & 1.82 & 0.88 & 0.83 & 0.98 & 0.98 & 0.97 & 0.066 \\
\hline Perfectionism & 47.69 & 24 & 1.98 & 0.95 & 0.90 & 0.96 & 0.96 & 0.94 & 0.072 \\
\hline Emotional Exhaustion & 36.58 & 18 & 2.03 & 0.91 & 0.84 & 0.97 & 0.97 & 0.95 & 0.074 \\
\hline Job Embeddedness & 5.15 & 5 & 1.03 & 0.99 & 0.97 & 1.00 & 1.00 & 1.00 & 0.012 \\
\hline
\end{tabular}

\subsection{Data Analysis}

SPSS for Windows 20.0 and Lisrel 8.80 programs were used to analyze the obtained data. After the exploratory and confirmatory analysis, descriptive statistics such as means, standard deviations and pearson correlation analysis of the study variables were examined. Following that, hierarchical multiple regression analysis was used to test all research hypotheses. 


\section{RESEARCH FINDINGS}

\subsection{Respondent Profile}

$52 \%$ of the employees' were female and $48 \%$ were male. $52 \%$ of the employees were between the ages $30-39,33 \%$ of them between the ages $20-29$. $15 \%$ of the older than 39 . In terms of education level, majority (81\%) of the respondents had a bachelor's degree, $19 \%$ had a graduate degree. When the titles of employees analyzed, it is seen that $26 \%$ of them working as a branch manager, $24 \%$ of the employees working as an executive and $20 \%$ of them as a manager. In addition, $30 \%$ of them working as an official. $42 \%$ of the participants had been working for between $1-5$ years and $30 \%$ of them have been working for between $6-10$ years and $28 \%$ of them had been working for more than 10 years in the same company.

\subsection{Descriptive Analyses}

In the scope of the descriptive analyses means, standard deviations and correlations have been conducted which are related to quality of work life, job embeddedness, emotional exhaustion and perfectionism. The values are given in Table 2.

Table 3: Means, Standard Deviations and Correlations of the Study Variables

\begin{tabular}{|c|c|c|c|c|c|c|}
\hline & Mear & S.S & 1 & 2 & 3 & 4 \\
\hline QWL & 3.52 & .81 & 1 & & & \\
\hline Job Embeddedness & 3.29 & .54 & $.362 * *$ & 1 & & \\
\hline Emotional Exhaustion & 3.47 & .51 & $-.280 * *$ & $-.295 * *$ & 1 & \\
\hline Perfectionism & 2.83 & .82 & .250 & $.412 * *$ &.$-400 * *$ & 1 \\
\hline
\end{tabular}

According to the Table 3, the results of the correlation analysis shows that there is a positive relationship between employees' perception of quality of work life and job embeddedness levels $(r=.362, p<0.01)$ and also there is a positive relationship between quality of work life and $(r=.250, p<0.01)$ perfectionism. In addition, quality of work life negatively related to the employees' emotional exhaustion levels ( $r=-$ $.280, p<0.01)$. While job embeddedness positively related to the perfectionism $(r=.412, p<0.01)$ levels of employees, it is related to the emotional exhaustion levels of employees negatively $(r=-.295, p<0.01)$. However, there is a negative and significant relationship between employees' emotional exhaustion levels and the perfectionism $(r=-.400, p<0.01)$. In this context, it can be interpreted that perception of quality of work life are much more related to the job embeddedness levels of employees.

\subsection{Hierarchical Regression Analysis}

Hierarchical multiple regression analysis was used to test all the research hypotheses and the mediating effects. The approach by Baron and Kenny (1986) was used to test mediating effects. In this study, whether perfectionism was a mediating variable or not was investigated.

Table 4: The Mediating Role of Perfectionism on the Effect of Quality of Work Life on Job Embeddedness and Emotional Exhaustion

\begin{tabular}{|c|c|c|c|c|c|c|}
\hline Model & Independent Variables & $\begin{array}{l}\text { Dependent } \\
\text { Variable }\end{array}$ & $\mathbf{R}^{2}$ & $\beta$ & $\mathbf{F}$ & $\mathbf{p}$ \\
\hline \multirow{2}{*}{1} & \multirow[b]{2}{*}{ QWL } & $\begin{array}{l}\text { Job } \\
\text { Embeddedness }\end{array}$ & .131 & $.541 * *$ & 28.570 & .000 \\
\hline & & $\begin{array}{l}\text { Emotional } \\
\text { Exhaustion }\end{array}$ & .079 & $-.479 * *$ & 16.132 & .000 \\
\hline \multirow{2}{*}{$\begin{array}{l}2 \\
\text { Model Included } \\
\text { Mediating } \\
\text { Variable } \\
\text { Perfectionism }\end{array}$} & $\begin{array}{l}\text { QWL } \\
\text { Sobel test: } z=2.717 \\
p=0.00658\end{array}$ & $\begin{array}{l}\text { Job } \\
\text { Embeddedness }\end{array}$ & .242 & $.413^{* *}$ & 29.930 & .000 \\
\hline & $\begin{array}{l}\text { QWL } \\
\text { Sobel test: } z=3.066 \\
p=0.00216\end{array}$ & $\begin{array}{l}\text { Emotional } \\
\text { Exhaustion }\end{array}$ & .195 & -.329 & 22.777 & .000 \\
\hline
\end{tabular}

According to the table 4 , while quality of work life $(\beta=.541, p<0.001)$ has positive and significant effect on employees' job embeddedness levels, it has a negative effect on emotional exhaustion $(\beta=-.479, p<0.001)$ levels of employees, so $\mathrm{H}_{1}$ and $\mathrm{H}_{5}$ hypotheses were supported. In addition to this, while perfectionism has a negative and significant effect $(\beta=-.730, p<0.001)$ on employees' emotional exhaustion levels, it has a positive and significant effect on job embeddedness $(\beta=.656, p<0.001)$ levels of employees so $\mathrm{H}_{2}$ and $\mathrm{H}_{3}$ hypotheses were supported. Moreover, considering the mediator role of perfectionism, it has been observed that the effects of quality of work life $(\beta=.413$, p<0.001) on job embeddedness has been continued but decreased. However, it is seen that the effects of quality of work life $(\beta=-.329$, $p<0.001)$ on emotional exhaustion also has been continued but decreased. Therefore, it can be claimed that the conditions of Baron and Kenny approaches were provided and perfectionism has a partially mediator role on the relationship between the quality of work life and job embeddedness. In addition, perfectionism has also partially mediator role on the relationship between the quality of work life and emotional exhaustion. Finally, $\mathrm{H}_{4}, \mathrm{H}_{6}$ and $\mathrm{H}_{7}$ hypotheses were supported. 


\section{CONCLUSION}

In today's modern business area, organizations need to maintain positive working conditions in order to gain benefit from their human resources. Due to the human resources are considered as a crucial component which facilitate to obtain organizational success, it is required to give more attention to the working conditions. In other words, when organization establish favorable, fair, safe and healthy working conditions, employees may have more willingness to perform their roles effectively and tend to exhibit more positive attitudes. However, it can be inferred that positive climate which represent quality of work life brings positive and negative consequences for both employees and organizations. From the previous studies, it is seen that there are various individual and organizational consequences of quality of work life were examined such as organizational commitment, work engagement, job satisfaction, job performance, organizational citizenship behavior, job involvement, turnover intention, absenteeism, job embeddedness and emotional exhaustion. Therefore, in scope of this study, both some individual and organizational consequences of quality of work life has been evaluated. That is to say, from the individual perspective perfectionism levels of employees and in terms of organizational consequences job embeddedness and emotional exhaustion were examined.

As a result of the research findings, it has been revealed that quality of work life has a significant and positive effect on employees' job embeddedness levels, so $\mathrm{H}_{1}$ was supported. According to this result, it can be inferred that when the employees perceive positive working conditions such as adequate and fair compensation, opportunities for development, favorable human resource practices, support from their colleagues and supervisors, social integration with the organization and etc., they may have willingness to stay and tend to committed to their organization. In addition, it has been obtained that quality of work life has a significant and negative effect on employees' emotional exhaustion levels, so $\mathrm{H}_{5}$ was supported. This result shows that, working conditions in scope of the companies lead employees' exhaustion levels may decrease. In other words, it is possible to express that there is a quality of work life and positive conditions in these companies so employees have no feelings of depletion, energy loss and extreme tiredness. However, it was found that quality of work life has a positive and significant effect on employees' perfectionism levels and $\mathrm{H}_{4}$ was supported. This result revealed that due to the positive working conditions, employees have more willingness to acquire success, prone to determine high performance standards and avoid from failure. Moreover, it is seen that while perfectionism levels have a positive and significant effect on job embeddedness, it has a negative and significant influence on the emotional exhaustion levels of employees, $\mathrm{H}_{2}$ and $\mathrm{H}_{3}$ were supported. Thus, it can be inferred that desire for obtain success and overextended expectations may lead employees to have more positive attitudes towards to their organizations. In addition, based on the perfectionist employees have more positive feelings, it is not expected them to have energy loss, extreme stress and fatigue. It was drawn from the research results, considering the mediator role of perfectionism, it was found that perfectionism had a partially mediator role on the relationship between quality of work life and job embeddedness, so $\mathrm{H}_{6}$ was supported. According to this result, it can be said that employees job embeddedness levels may increase in case of both they perceived quality of work life and possess a perfectionism. Besides, it was found that perfectionism had a partially mediator role on the relationship between quality of work life and emotional exhaustion, $\mathrm{H}_{7}$ was supported. It can be inferred that employees' emotional exhaustion levels may decrease in case of both they perceived quality of work life and have a perfectionist tendency.

Therefore, it is possible to express that positive and negative attitudes of employees based on the organizational conditions that they perceived and depend on their individual characteristics. In the literature, there are some studies related to the individual and organizational consequences of quality of work life but it is seen that researches which focus on quality of work life, perfectionism, job embeddedness and emotional exhaustion are relatively scant in the banking industry. Due to the banking industry's working conditions such as work overload, long working hours, high demands and mental fatigue, it is seen maintaining positive working conditions become more important. Based on the research results, it can be supposed to the companies to establish fair, transparent, healthy and safe conditions which lead employees to exhibit positive attitudes and to have positive feelings. In other words, because of the quality of work life perception in scope of the companies, employees' feelings and attitudes are more desirable levels. For future studies, it is recommended that the research model can be tested different samples such as health, tourism and retailing which have a heavy conditions like banking industry. Furthermore, some individual consequences of work life quality such as self-esteem, locus of control and self-efficacy can be examined and from the organizational perspective job involvement and positive organizational behaviors can be questioned.

\section{REFERENCES}

Ajala, E. M. (2013). Quality of work life and workers wellbeing: the industrial social workers approach. Ife PsychologIA, 21(2), p. 46-56.

Akpınar, A. T., Taş, Y., Okur, M. E. (2013). The effect of job satisfaction and emotional exhaustion on affective commitment of emergency services employees. British Journal of Economics, Finance and Management Sciences, 7 (2), p. 169-176.

Alqarni, S. A. Y. (2016). Quality of work life as a predictor of work engagement among the teaching faculty at King Abdulaziz University. International Journal of Humanities and Social Science, 6(8), p. 118-135.

Baron, R. M., Kenny, D. A. (1986). The moderator mediator variable distinction in social psychological research: conceptual, strategic, and statistical considerations. Journal of Personality and Social Psychology, 51, p. 1173-1182.

Crossley, C., Bennett, R. J., Jex, S. M., Burnfield, J. L. (2007). Development of a global measure of job embeddedness and integration into a traditional model of voluntary turnover. Management Department Faculty Publications. Paper 34, p. 1030-1042.

Dawley, D. D., Andrews, M. C. (2012). Staying put: off-the-job embeddedness as a moderator of the relationship between on-the-job embeddedness and turnover intentions. Journal of Leadership \& Organizational Studies, 19(4), p. 477-485. 
Edais, S. N. (2013). Personality variables, job embeddedness and job outcome: a study in Jerusalem, Israel. Degree of Master of Science in Tourism Management, Eastern Mediterranean University, Gazimağusa, North Cyprus.

Forghani, M. H., Ghafari, M., Shirangi, S. Y., Ghandehari, F., Emadzadeh, M. K. (2013). The role of personality traits in perfectionism orientation, (Isfahan Melli Bank employees as case study). International Journal of Academic Research in Accounting, Finance and Management Sciences, 3 (1), p. 52-59.

Ganguly, R. (2010). Quality of work life and job satisfaction of a group of university employees. Asian Journal of Management Research, ISSN 2229-3795, p. 209-216.

Giosan, C. (2003). Antecedents of job embeddedness, doctoral dissertation, faculty of political and social science of the New School University.

Gong, Y. (2009). Who will stay? Examination of employees' job embeddedness and turnover from a dispositional perspective. Degree of Master of Philosophy III Management. The Chinese University of Hong Kong.

Gupta, M., Sharma, P. (2011). Factor credentials boosting quality of work life of Bsnl employees in Jammu Region. APJRBM, ISSN 22294104, 2(1), p. 80-89.

Halbesleben, J. R. B., Wheeler, A. R. (2008). The relative roles of engagement and embeddedness in predicting job performance and intention to leave. Work \& Stress, 22 (3), p. 242-256.

Huysse-Gaytandjievaa, A., Bosb, A., Alberts, H., Meesters, C., Hom, P. (2016). Dark side of job embeddedness. p. 1-41.

Kanten, P. (2014). Effect of quality of work life (Qwl) on proactive and prosocial organizational behaviors: a research on health sector employees. Suleyman Demirel University, the Journal of Faculty of Economics and Administrative Sciences, 19(1), p. 251-274.

Kanten, P., Kanten, S., Gürlek, M. (2015). The effects of organizational structures and learning organization on job embeddedness and individual adaptive performance. Procedia Economics and Finance, 23, p. 1358-1366.

Kanten, P., Yesıltas, M. (2015). The effects of positive and negative perfectionism on work engagement, psychological well-being and emotional exhaustion. Procedia Economics and Finance, 23, p. 1367-1375.

Karatepe, O. (2013). The effects of work overload and work-family conflict on job embeddedness and job performance, the mediation of emotional exhaustion. International Journal of Contemporary Hospitality Management, 25 (4), p. 614-634

Kashani, F. H. (2012). A review on relationship between quality of work life and organizational citizenship behavior (Case Study: An Iranian Company). Journal of Basic and Applied Scientific Research, 2(9), p.9523-9531.

Khoo, E. J., Aldubai, S., Ganasegeran, K., Bernice, X. E. L., Zakaria, N. A., Tan, K. (2017). Emotional exhaustion is associated with work related stressors: a cross-sectional multicentre study in Malaysian public hospitals. Arch Argent Pediatr, 115(3), p. $212-219$.

Korunka, C., Hoonakker, P., Carayon, P. (2007). Job and organizational factors as predictors of quality of working life and turnover intention in IT work places. In R. Rau., S. Mühlpfordt \& P. Richter (Hrsg.), Arbeit und Gesundheit. München: Papst Publishers.

Lai, S. L., Chang, J., Hsu, L. Y. (2012). Does effect of workload on quality of work life vary with generations?. Asia Pacific Management Review, 17(4), p. 437-451.

Madjar, N., Voltsis, M., Weinstock, M. P. (2015). The roles of perceived parental expectation and criticism in adolescents' multidimensional perfectionism and achievement goals. Educational Psychology, 35(6), p. 765-778.

Marofi, M., Mousaviasl, F., Hemati, Z. (2016). The relationship between burnout and quality of work life in pediatric and neonatal intensive care unit nurses. Iranian Journal of Pediatric Nurses, 3(1).

Meydan, C. H., Şeşen, H. (2011). Yapısal eşitlik modellemesi AMOS uygulamaları. Ankara: Detay Yayıncılık.

Nair, G. S. S. (2013). A study on the effect of quality of work life (QWL) on organisational citizenship behaviour (OCB). Integral Review A Journal of Management, 6(1), p. 34-46.

Ozbilir, T., Day, A., Catano, V. M. (2015). Perfectionism at work: an investigation of adaptive and maladaptive perfectionism in the workplace among Canadian and Turkish employees. Applied Psychology: An International Review, 64 (1), p. $252-280$.

Parvar, M. R. F., Allameh, S. M., Ansari, R. (2013). Effect of quality of work life on organizational commitment by SEM (Case Study: OICO Company). International Journal of Academic Research in Business and Social Sciences, 3(10), p. 135-144.

Penny, W. Y. K., Joanne, C. S. H. (2013). Casino employees' perceptions of their quality of work life. International Journal of Hospitality Management, 34, p. 348-358.

Rice, K. G., Richardson, C. M. E., Tueller, S. (2014). The short form of the revised almost perfect scale. Journal of Personality Assessment, 96(3), p. 368-379.

Schermelleh-Engel, K., Moosbrugger, H., Müller, H. (2003). Evaluating the fit of structural equation models: tests of significance and descriptive goodness-of-fit measures, Methods of Psychological Research, 8(2), p. 23-74. 
Tabassum, A., Rahman, T., Jahan, K. (2011). A comparative analysis of quality of work life among the employees of local private and foreign commercial banks in Bangladesh. World Journal of Social Sciences, 1(1), p. 17-33.

Taher, A. (2013). Variations of quality of work life of academic professionals in Bangladesh, a discriminant analysis. European Journal of Training and Development, 37(6), p. 580-595.

Timossi, L. S., Pedroso, B., Francisco, A. C., Pilatti, L. A. (2008). Evaluation of quality of work life: an adaptation from the Walton's QWL model. XIV International Conference on Industrial Engineering and Operations Management, Rio de Janeiro, Brazil, 13 to 16 October.

Tulasi, D. V., Vijayalakshmi, C. (2013). Quality of work life - a strategy for good industrial relations. Advances in Management, 6(11), p. 8-15.

Tuuli, P., Karisalmi, S. (1999). Impact of working life quality on burnout. Experimental Aging Research, 25, p. $441-449$.

Zhao, X., Sun, T., Cao, Q., Li, C., Duan, X., Fan, L., Liu, Y. (2012). The impact of quality of work life on job embeddedness and affective commitment and their co-effect on turnover intention of nurses. Journal of Clinical Nursing, 22, p. 780-788.

Walton, R. E. (1974). Improving the quality of work life. Harvard Business Review.

$\mathrm{Wu}, \mathrm{T} ., \mathrm{Hu}, \mathrm{C}$. (2009). Abusive supervision and employee emotional exhaustion dispositional antecedents and boundaries. Group \& Organization Management, 34 (2), p. 143-169.

Yao, X., Lee, T. W., Mitchell, T. R., Burton, J. P., Sablynski, C. J. (2004). Job embeddedness: current research and future directions. In R.W. Griffeth \& P. Hom (Eds), Innovative theory and empirical research on employee turnover (pp. 153-187). Greenwich, CT: Information Age. 